Archived version from NCDOCKS Institutional Repository http://libres.uncg.edu/ir/asu/

\title{
Appalachiłąn
}

B O O N , N O R T H C A R O L I N A

\section{Tourism Development In The Dominican Republic: An Examination Of The Economic Impact To Coastal Households}

\author{
By: Lauren N. Duffy, Garrett Stone, H. Charles Chancellor, \& Carol S. Kline
}

\begin{abstract}
Coastal tourism projects are promoted in the Dominican Republic as national-level economic development initiatives that will create jobs for local residents, subsequently benefiting the households in these commu- nities. However, the economic benefits of tourism can be severely weakened as a result of the neoliberal economic policies that guide such projects. Like other economically developing countries-particularly small island nations-the Dominican Republic embraced neoliberal policies that have ultimately reshaped the country's economic, political, cultural, and physical landscape. As a result, transnational companies, foreign investors, and large-scale enclave tourism projects are the dominant form of tourism development in the Dominican Republic. Though companies' revenue and profit data are not available for analysis of economic leakage, households can be investigated to understand the level of economic benefits obtained by residents of the local communities. Toward this end, 360 household surveys were collected to examine household income and material assets across 12 coastal communities in three regions of the Dominican Republic. Because of the noted differences in previous development literature, gender of the head of households and whether the household was dependent on income from tourism employment were compared across these measures after adjusting for regional differences. Results indicate that the gender of the head of the household and tourism dependency positively predicted household income, while only gender of the head of the household predicted material assets.
\end{abstract}

Duffy, L. N., Stone, G., Chancellor, H. C., \& Kline, C. S. (2016). Tourism development in the Dominican Republic: An examination of the economic impact to coastal households. Tourism and Hospitality Research, 16(1), 35-49. https://doi.org/10.1177/1467358415613118. Publisher version of record available at: https://journals.sagepub.com/ doi/full/10.1177/1467358415613118 


\title{
Tourism development in the Dominican Republic: An examination of the economic impact to coastal households
}

\author{
Lauren N Duffy, Garrett Stone and H Charles Chancellor \\ Clemson University, USA
}

Carol S Kline

Appalachian State University, USA

\begin{abstract}
Coastal tourism projects are promoted in the Dominican Republic as national-level economic development initiatives that will create jobs for local residents, subsequently benefiting the households in these communities. However, the economic benefits of tourism can be severely weakened as a result of the neoliberal economic policies that guide such projects. Like other economically developing countries-particularly small island nations-the Dominican Republic embraced neoliberal policies that have ultimately reshaped the country's economic, political, cultural, and physical landscape. As a result, transnational companies, foreign investors, and large-scale enclave tourism projects are the dominant form of tourism development in the Dominican Republic. Though companies' revenue and profit data are not available for analysis of economic leakage, households can be investigated to understand the level of economic benefits obtained by residents of the local communities. Toward this end, 360 household surveys were collected to examine household income and material assets across 12 coastal communities in three regions of the Dominican Republic. Because of the noted differences in previous development literature, gender of the head of households and whether the household was dependent on income from tourism employment were compared across these measures after adjusting for regional differences. Results indicate that the gender of the head of the household and tourism dependency positively predicted household income, while only gender of the head of the household predicted material assets.
\end{abstract}

\section{Keywords}

Political economy, neoliberalism, Dominican Republic, economic impact, social justice

\section{Introduction}

Tourism researchers are questioning the unchecked acceptance of a neoliberal capitalist ideology that has uncritically been guiding tourism development (Ateljevic et al., 2012; Bianchi, 2009). As a political practice, tourism has the potential to exacerbate inequalities of class, gender, and race (Bianchi, 2009; Hall, 1994); conversely, if planned and managed correctly, with the explicit inclusion of local communities and focus on the redistribution of costs and benefits spread across all stakeholders, tourism can lead to equality, equity, and justice (Higgins-Desbiolles, 2008). In the contexts of lesser economically developed countries (LEDCs), and small island nations such as the Dominican Republic (DR), the global political economy has created a situation ripe for foreign investment, the establishment of transnational and multinational companies (TNCs/ $\mathrm{MNCs}$ ), and the growth of enclave tourism development, which are likely to intensify inequality and inequity in the region.

\section{Corresponding author:}

Lauren N Duffy, Clemson University, 128 McGinty Court, 294 Lehotsky Hall, Clemson, SC 29634-0735, USA.

Email: Iduffyaclemson.edu 
This study examines the economic impact of tourism on household income and material assets in coastal communities; differences based upon head of the household gender and household tourism dependency are investigated, adjusting for regional differences. The findings relate to the broader discussion of the political economy in the DR and contribute to the literature by critically analyzing these tourism impacts across gender in rural coastal communities. Furthermore, this study applied a social justice framework which utilizes a distributive paradigm to understand how social costs and benefits, such as wealth, income, and material resources are dispersed among societal populations. Distributive patterns in tourism are situated within historical and political contexts and are directly influenced by power relations dictated by social constructions of gender, class, and race (Ferguson, 2010b; Hall, 1994). Embedded in the politics of tourism, power plays an important role in decision-making and the subsequent distribution of the costs and benefits of tourism development (Hall, $1994,2003)$. The unequal distribution of impacts is often detrimental to marginalized groups, which include those of lower economic class and women (David, 2002). Within the context of this study, the effects of the global political economy and neoliberalism on a small island nation are explored by investigating the economic impact of tourism at the household level.

\section{Study site}

Though the DR entered the Caribbean tourism industry late, it quickly became one of the strongest destinations in the region. International tourist arrivals to the DR grew an average of $9 \%$ per year between 1993 and 2002, and increased from 3,282,000 in 2003 to $4,125,000$ in 2010, after holding steady during the 2008-2009 economic recession (World Data Bank, 2013). Tourism propelled the DR into being an upper-middle-income country with one of the largest economies in Central America and the Caribbean (World Data Bank, 2013). In 2011, with 66,790 hotel rooms, tourism accounted for $4.7 \%$ of the total gross domestic product (GDP), and directly or indirectly supported $14 \%$ of all employment in the country (Association of Hotels and Tourism in the Dominican Republic and the Central Bank of the Dominican Republic, 2013; WTTC, 2012), though many of the rooms are concentrated within just a few tourism establishments, reflecting the dominant form of tourism development (see Barrera et al., 2008).

As such, most of the DR's large-scale tourism development is characterized by foreign ownership and investment (see Sasidharan and Hall, 2012). For example, Carnival Cruise, Inc. has invested USD $\$ 85$ million to develop the "Amber Cove" cruise terminal on the North Coast outside of the City of San Felipe de Puerto Plata (Puerto Plata), set to open in October 2015. Former Tourism Minister Francisco Javier Garcia stated that the project was to move quickly, "mostly because [this] investment doesn't require any financing or Dominican Government facilities for the investors" (Dominican Today, 2011: para. 3). In the Eastern Punta Cana region, there were over 50 foreign firms who initially invested approximately USD $\$ 800$ million in the 30,000 acre Cap Cana luxury resort. The unprecedented project included approximately $5 \mathrm{~km}$ of coastline, million dollar homes, worldclass golf courses, amenities, and hotels, contained within a secure, gated community (Classical Reality International, n.d.). AMResorts, a subsidiary of the U.S. Apple Leisure Group, owns six resort brands and in early 2015, they announced two new DR resort contracts, one adjacent to the Cap Cana luxury community and the other in the Southeast La Romana-Bayahibe area (Hotel News Resource, 2015). These examples typify the size, scope, and hegemonic nature of DR tourism projects, which often make it difficult for local communities to enter the planning discourse, open tourism businesses, or participate in the industry except as low-level employees (Brennan, 2004; Hall, 1994).

Development at this scale requires substantial capital and credit lines, which local entrepreneurs in LEDCs often do not have access to (Hall and Lew, 2009). Likewise, foreign tourism companies from more economically developed countries (MEDCs) have access to managerial expertise, marketing skills, and professional networks that outcompete local businesses. These projects often import outside employment and repatriate profits to their countries of origin, further reducing local residents' economic opportunities and preventing the lowest earners in small island states to advance economically (Scheyvens and Momsen, 2008). Moreover, enclave tourism development or the "all inclusive" resort model is comprised of self-sufficient properties that give tourists little reason to leave the property, which reduces opportunities for the development of the informal tourism sector (Carlisle, 2010). Enclave tourism also stresses the environmental, cultural, and social resources; reduces local access to resources; causes resident displacement; and creates a sense of powerlessness (Buncic, 2008; Carlisle, 2010; Freitag, 1994, 1996). Yet, this neoliberal tourism development strategy has been supported because of the suggested "trickledown effect" of money and capital to lower socioeconomic classes that should result (Bianchi, 2009; Brennan, 2004). By exploring the impact of neoliberal tourism 
development on household income and material assets, manifested in large-scale enclave tourism development, this study indirectly investigates the extent to which economic impacts are trickling down to the local communities impacted by this type of development.

\section{Political economy}

Political economy refers to the production, accumulation, and distribution of wealth within a society, including the role of government and how political behavior influences the structure of the economy (Bramwell, 2011; Mosedale, 2011; Williams, 2004). Since "economic relations permeate in all aspects of our everyday lives" (Bianchi, 2009: 488), the critical questions that should be asked include: who controls economic policy and processes?, Who benefits from the policies and processes?, and Who is impacted by the consequences of the policies and processes? (Hall and Lew, 2009). Scholars have previously noted the paucity of tourism research that has considered the role of the political economy given its relevancy to the discussion of tourism impacts and sustainable development (Bramwell, 2011; Mosedale, 2011; Williams, 2004).

Important to the context of the DR, is investigating the political economy between LEDCs and MEDCs, which is also discussed as the distribution of wealth across the Global North-South divide. Embedded in the tenets of Marxism, dependency theory was popularized in Paul Baran's (1957) The Political Economy of Growth, which suggests that current development is influenced and situated within the historical condition of LEDCs being dependent on MEDCs. In this regard, MEDCs growth comes "at the cost of, and often on the backs of, the developing nations" (Wiarda, 2005: 30). Dependency theory originated after a critical analysis of economic development in Latin America, which employed this "outwardoriented model in which the region provided primary goods to Euro-American markets" (Peet, 1991: 43). The political economy of Latin America must be considered within the historical effects of colonialism, and neocolonialism, the continued economic imperialism that persists through global capitalism. Andre Frank (1967), and other world-systems theory thinkers, proposed that slow economic development, or underdevelopment of Latin America, is not caused by "backwardness" - a tenet of modernization theory which had previously dominated discourse-but rather, is a result of continuous economic disadvantage and pillaging of resources.

Political and economic conditions in the DR. Like many small island states, the DR has experienced political, social, and economic issues that influenced its pace of development. The DR gained independence from Spain in 1865, was occupied by the U.S. between 1916 and 1924, and was ruled by successive dictatorships culminating in the repressive reign of Rafael Trujillo. The first democratically held election was in 1996; however, political corruption is still rampant (Ferguson, 2001b). Agricultural commodities, primarily tobacco, coffee, cocoa, and sugar, drove the DR economy through the 1970s (Pozo et al., 2010). The mid-1980s and 1990s saw drastic inflation, devaluation of the DR Peso, rising unemployment rates, and deteriorating income levels, all of which increased the poverty level (Ferguson, 2001a). This was in part a result of the privatization of sugarcane production and the collapse of coffee prices, which triggered a need to diversify the Dominican economy.

As a condition to secure international loans from agencies such as the International Monetary Fund and World Bank, the DR was required to open its borders to international trading, lifting trade barriers and government controls, and implementing new economic policies that encouraged further globalization. These economic policies are known as structural adjustment policies (SAPs) and are reflective of neoliberal ideology. They involve a combination of short-term strategies aimed at stabilization and long-term structural reforms aimed at transforming state-controlled economies into global market economies (Gregory, 2007). For example, free trade zones (FTZs), or designated areas near transportation hubs that could receive material goods from across the globe for further manufacturing and reexporting without interference from the government, appeared in the DR at this time (Pozo et al., 2010). Economic incentives, including attractive taxation and a cheap labor force, also encouraged TNCs to take advantage of the open borders and invest in, or relocate facilities to, the DR. Specifically, the foreign direct investment law (or Tourist Incentive Law) was also established during this time, which eliminated restrictions on foreign tourism investment and encouraged large-scale enclave tourism in special economic zones similar in concept to the FTZs (Freitag, 1994; Pozo et al., 2010; Roessingh et al., 2008). Since tourism in the $\mathrm{DR}$ is developed in rural areas lacking necessary infrastructure (e.g. water treatment, sewage, stable electricity), developers are granted concessions and are exempt from certain costly policies. At the national level, foreign tourism development was initially encouraged to increase economic diversification, though indicators suggest that the DR is increasingly dependent on tourism (Freitag, 1994; Wilkinson, 1989, 2009). Nonetheless, it is within this context that the stage was set for the foreign-owned, large-scale tourism development model to dominant the landscapes in the coastal regions. 
And while the benefits accrue for the TNCs, neoliberal economic policies and SAPs have more recently been criticized for not creating their intended trickledown economic effect because the jobs they produce are often low paying and seasonal. Furthermore, much of the social welfare burden has been transferred from the state to families through the cutting of social support programs, which further oppresses vulnerable and disenfranchised groups such as women and the poorest sectors of society (Connelly et al., 2000; Momsen, 2004). Since these policies resulted in less spending on social programs and few economic opportunities, Dominicans began relying more on the informal employment sector, remittances from abroad, and the opportunities of temporary or permanent migration as revenue streams that could increase their household income; moreover, they have had to move away from single-earner households and rely on dual/ multiple incomes (Cabezas, 2004; Gregory, 2007).

As a result of these economic conditions, in 2003 inflation skyrocketed to $42.7 \%$ (Barrera et al., 2008) and by $2004,3 \%$ of the population was in extreme poverty (World Data Bank, 2013). However, by 2007 inflation had stabilized and tourism development resumed (Barrera et al., 2008), with only $2.39 \%$ of the DR population (total pop $=99,270,000$ ) living in poverty in 2010 (World Bank Data, 2013). Still, like many Latin American countries, the DR has high levels of income inequality (Hammill, 2005). Using the GINI Index, which measures the degree of inequality in the distribution of income or wealth, the World Bank scored the $\mathrm{DR}$ at $47.2 \%$ in 2010 , as $10 \%$ of the population made $36.4 \%$ of all income, while the bottom $10 \%$ made $1.8 \%$ (World Data Bank, 2013). Reducing levels of poverty, in conjunction with creating a more balanced distribution of income, stronger public institutions, and improved basic services for residents, remains as important development goals (Barrera et al., 2008). However, the DR has one of the lowest ratios of social spending to GDP compared to other Latin American countries (Hammill, 2005).

The DR also faces high unemployment; 2010 data indicate a $69 \%$ labor force participation rate for those between the ages of 15 and 64 (World Data Bank, 2013). In 2013 the International Monetary Fund noted that although the DR maintained high rates of output and productivity growth, employment rates remained weak during the last 20 years, and that jobs are continuing to be low status and pay (Abdullaev and Estevao, 2013). The report also cited rampant labor market informality, inequality, and poverty as factors contributing to the imbalance in employment creation.

Unemployment in the DR, as in other LEDCs takes on various forms (Bulmer-Thomas, 2012). Seasonal unemployment occurs when there is a reduced demand, thus reduced need for labor, at a specific time of the year (e.g. "tourist off-season"), which results in higher unemployment. "Disguised" unemployment occurs when there is an excess of labor such that an individual's productive value is lessened or becomes redundant because there are fewer vital jobs than there are employees (Wellisz, 1968). It has historically been a recurring issue in many Caribbean nations including $\mathrm{Cuba}$ and Guyana, though the DR has more recently experienced problems with open unemployment (Bulmer-Thomas, 2012). Open unemployment in the $D R$ is believed to occur where laborers are not compensated in a way that matches their level of skill or education, a symptom of neoliberal economic policy. Abdullaev and Estevao (2013) argue that "low employment rates in tandem with low open unemployment rates point to low labor force participation as a significant labor market problem in the Dominican Republic" (p. 6).

Broad unemployment rates are also connected to crime and incarceration rates to some extent. In a 2014 report, the U.S. Department of State, claimed the crime rate in DR is "high" with the International Center for Prison Studies (ICPS) indicating that for every 100,000 DR residents, 233 are incarcerated (relatively high per 100,000 residents compared to some of its neighbors; e.g. Jamaica (145), Haiti (97) and low compared to others; e.g. Puerto Rico (351). While unemployment was listed as a contributor to crime and incarceration in the DR, incarcerated individuals are not included in calculations of unemployment as defined by the World Data Bank (2013). Thus, it is difficult to determine exactly how crime and subsequent incarcerations affect unemployment rates and consequently household income in the DR. It should be noted, however, that men and women are equally represented in open unemployment rates, while broader unemployment is higher $(58 \%)$ for women. Open unemployment is also highest for youth and first time job seekers in the DR (Abdullaev and Estevao, 2013). With only 2.3\% of the prison population in the DR comprised of youth and $2.5 \%$ of the prison population comprised of women, it would appear that incarceration is not a major contributor to open or broad unemployment in the DR, were these numbers to be included in the calculation of unemployment (ICPS).

\section{Gender, development, and labor force participation}

Gender carries with it constructions of power, and thus, can impede or promote political participation and create differential outcomes for women and 
men in development projects (Momsen, 2004). Within Dominican communities, gender identity, relations, and roles are shaped by the traditional gender ideology, machismo-marianismo. Gendered divisions of labor continue to be defined by this ideology because it created separate spheres where "men's place is in the public realm of 'la calle' (the street) and women's place is in the private realm of 'la casa' (the home)" (Raynolds, 2002: 786). Researchers have investigated the way in which women are being involved in the labor force in LEDCs as global restructuring shifts them into the public sphere and challenges the traditional division of labor (Connelly et al., 2000).

As such, labor participation and the way women become active in employment outside the house needs to be examined. While neoliberal ideology has become the impetus for women to work outside of the household, they still face barriers related to challenging the traditional gender ideology that places them at a disadvantage in the job market. Young women are most affected by discrimination in the labor market, with a $39.3 \%$ unemployment rate for women between the ages of 15 and 29 compared to the $18.8 \%$ unemployment rate of men of the same age (Centro de Estudios de Género (CEG), 2012). In this regard, lack of access to jobs-and continued barriers to higher paying jobs by women-may lead to lower levels of household income, particularly for households headed by women. According to the Center for Gender Studies at the Instituto Tecnológico de Santo Domingo (CEG, 2012), in 2011 over three million people were registered as poor in the DR and $65 \%$ of these are households headed by women. Additionally, over half (51\%) of employed women are involved in the informal labor market, which results in higher levels of job insecurity and social vulnerability. The informal labor market is a part of a dual economic system in contrast to the "formal sector," is characterized by easy labor entry and family ownership, and is composed of unregulated institutions, often physically located within the household (Kermath and Thomas, 1992). Past research suggests that women are more likely to be involved in the informal labor market because it allows them to balance employment outside the household with their domestic and reproductive responsibilities (Duffy et al., 2012; Ferguson, 2010a).

\section{Methods}

This study examined the impact of tourism on household income and material assets in coastal communities, with a particular interest in differences across gender of the head of the household and tourism dependency. Examination of income and wealth distribution using the household as the unit of analysis does not come without its critiques. For example, some argue that such a simplistic approach may overlook exchanges of economic resources (Folbre, 1986; Raynolds, 2002). Because economic realities are experienced, felt, and shared at the household level, the researchers took care to ask detailed questions regarding economic generation by all members.

\section{Data collection}

During the summer of 2012, a local research team along with the primary investigator conducted inperson structured survey interviews using a household questionnaire. Aside from the primary researcher who was a Western, White woman, the research team included four Dominican women who helped collect data, translate, and provide local contextual information when necessary. While Dominican society is patriarchal, the data collectors did not detect any bias from respondents based on the forthright comments provided by both men and women.

Data were collected from 12 communities representing three coastal regions in the DR; the North, South, and East Coast (Figure 1, Table 1). These regions were identified for this study based on several sources of data: previous tourism research that had utilized locations in the DR and provided rich descriptions of the communities (Freitag, 1994, 1996; Gregory, 2007; Leon, 2007; Roessingh and Duijnhoven, 2005), travel guides (e.g. Lonely Planet, Fodors, and Frommer's), and the Ministry of Tourism Office (e.g. information from the official tourism website as well as phone calls to regional marketing offices in the U.S.).

Once the communities were selected, "barrios" (i.e. neighborhoods) were purposefully selected through observation and word of mouth. After neighborhoods were identified through spatial analysis using current satellite maps, systematic sampling was employed by selecting a central starting point or what would appear to be the "main street," and approaching every second house for inclusion in the study (side roads and connecting streets were also included). This procedure allowed for data collection throughout the heart of local residential communities. There were two data collection periods-morning and late afternoon; if less than 20 surveys were collected, a third round of data collection occurred. Heads of the household or their partners, over the age of 18 , were invited to participate in the survey.

\section{Instrument questions}

The household questionnaire was translated into Spanish by a native Dominican speaker and contained 


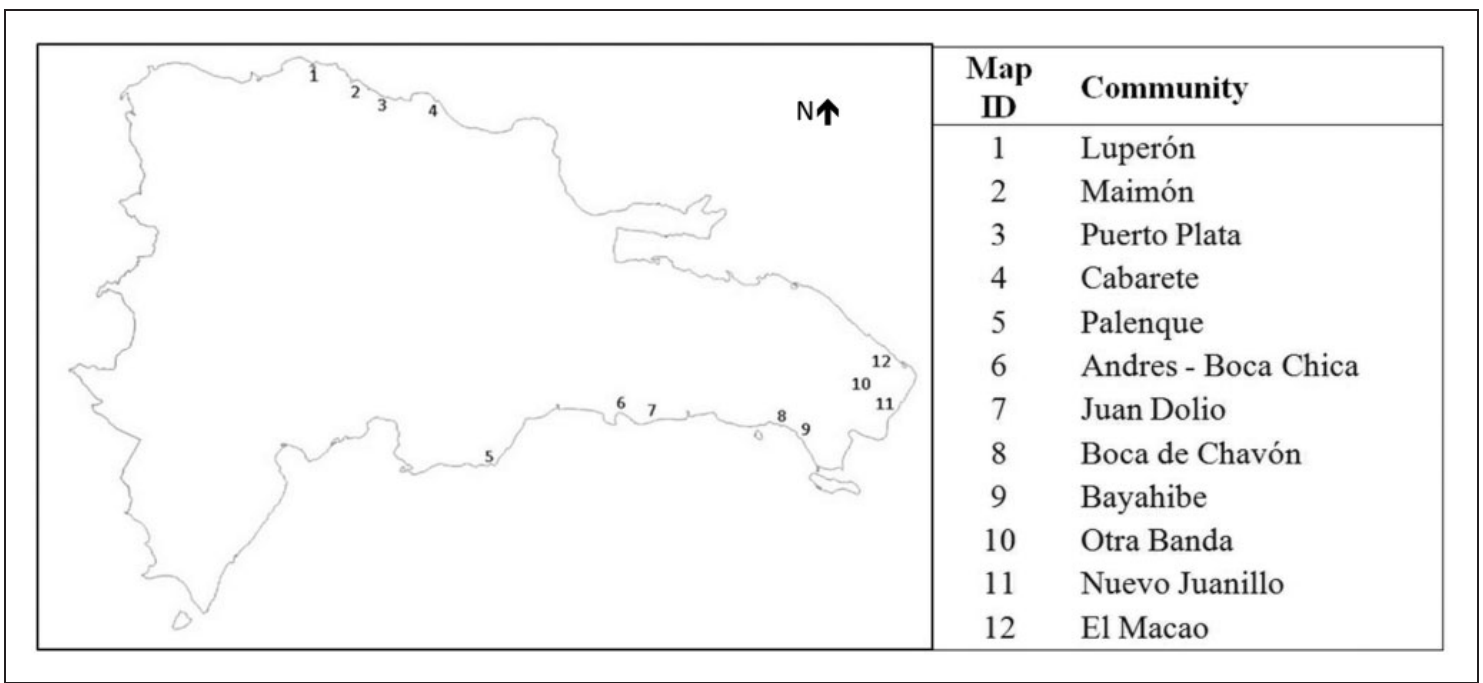

Figure 1. Map of communities surveyed in DR.

Source: Reprinted with permissions from Elsevier.

Table 1. Community descriptions.

Lupéron (pop. 20,000)

Located on the North Coast, $25 \mathrm{~km}$ west of the Puerto Plata Tourist Zone, it had traditionally been a coastal agricultural community before it became the center of enclave tourism between 1986 and 1995 (Freitag, 1994, 1996). The major mass tourist resort permanently closed in 2011, resulting in a drastic decrease in tourism. There remains a trickle of tourist activity from fishing vessels and sailboats who port in the Puerto Blanca Marina, but many of the tourist shops and restaurants have since closed (Duffy, 2013). Tourism money had improved community infrastructure (e.g. roads, sidewalks, lightingl but much of this has deteriorated with tourism's decline (Duffy, 2013; Freitag, 1994, 1996).

Maimón (pop < 1000)

This small community, $24 \mathrm{~km}$ west of Puerto Plata, was primarily a fishing village until the first hotel complex opened in 1998. Situated on a bay, in 2012, Carnival Cruise announced it would develop a new private port in the Maimón Bay (the Amber Cove), set to open at the end of 2015 (Duffy, 2013).

Puerto Plata (pop. 280,000)

San Felipe de Puerto Plata is the largest city in the Puerto Plata province. Of focus in this study was the Puerto Plata Tourist Zone $(60 \mathrm{~km}$ stretch between Maimón and Cabarete). This was the first area to receive attention from the newly formed INFRATUR (Department of Investment and Infrastructure) and was given USD \$76 million in World Bank funds in the 1970 s to develop a malecon and other tourist infrastructure, which has positioned it as the second most popular region for tourist arrivals. However, the city has been overrun by negative tourism impacts due to poor planning and control (e.g. environmental degradation, crime, prostitution, overcrowdingl, leading to a decline in tourism, major economic leakage, and poor reinvestment in the community (Freitag, 1994, 1996; Roessingh and Duijnhoven, 2005, 2008).

Cabarete (pop 40,000)

Cabarete, located $37 \mathrm{~km}$ east of Puerto Plata, has become a major destination for adventure sport tourists, particularly windsurfing and kitesurfing. Major accommodation development occurred in the 1990s and continues to attract investors for new condo development-one of the few locations on the North Coast that is still a thriving tourist destination (Duffy, 2013).

Palenque (pop 15,000)

Palenque (Sabana Grande de Palenque), located west of the capital city, Santo Domingo, has predominantly been a day-trip destination for regional locals. Multiple investors have attempted to purchase land for enclave development but plans have fallen through due to public outcry and lawsuits over property rights as it would limit public beach access (Duffy, 2013).

Andrés-Boca Chica

(pop $>120,000$ )

Andrés and Boca Chica are located $30 \mathrm{~km}$ southeast of Santo Domingo, nestled closely to the international airport, free trade zone, and major trading port. Andrés had traditionally been a sugar batey (company town) and agricultural community while Boca Chica had the sugar mill. Boca Chica eventually became a seaside resort town attracting both domestic and foreign travelers. However, through the complexities of globalization, it has become a hot spot for prostitution, sex tourism, and drugs. Additionally, after the 2010 Haiti earthquake, Haitian immigration has abounded in this area (Duffy, 2013; Gregory, 2007). 
Table 1. Continued.

Juan Dolio (pop. 3000)

Boca de Chavon (pop. <1000)

Bayahibe (pop. 2000)

Otra Banda (pop. 8000)

Nuevo Juanillo (pop. <500)

El Macao (pop. <500)
Juan Dolio, located $50 \mathrm{~km}$ southeast of Santo Domingo. In 1973, fishing access was limited by the government in order to increase tourism. Europeans became a major market as well as domestic wealthy families from Santo Domingo who purchased second homes that line the beach front, further limiting local access to the beach. In 1998, Hurricane Georges caused major damage to the community; instead of investing money to fix the damage, many of the private investors moved on to the more popular Punta Cana region. Highway 3 , designed to improve access to the beach, now creates a literal divide between the tourists/wealthy elite and local residents (Duffy, 2013).

Boca de Chavón receives little direct tourism to the community; however, most residents commute (sometimes for weeks) to other communities for tourism work such as, La Romana, Bayahibe, and Bávaro. The community is located next to Casa de Campo, one of the largest and longest standing all-inclusive resorts in the DR, and continues to face pressures from investors who want to purchase the community's land (Duffy, 2013; Leon, 2007).

Bayahibe, located $10 \mathrm{~km}$ east of La Romana, is insulated from many of the urban ills that face Boca Chica, Andres, and Juan Dolio. Tourism is the primary industry and is driven, in part, by the community's first class scuba diving opportunities. Traditionally, Bayahibe was a fishing village, but many of the fishermen became boat drivers to transport tourists over to Isla Saona. People in the community have grown dependent on tourism, and it has brought many positive aspects to the community including jobs and infrastructure such as medical services. While it sits near many large-scale enclave tourism developments in Punta Cana, the town itself has had smaller independently owned hotels established, though they are struggling to compete with the resorts (Duffy, 2013).

Otra Banda is an inland community in the La Altagracia province that sits on the outskirts of Higüey, a large working-class community. It "popped up" as a migrant tourism community where workers live and commute $30-45$ min to work each day via buses provided by the resorts. Though the houses were in relative good shape, there is no piped water. Additionally, many of the households in this community were not made up of family units but coworkers who migrated there for work. That said, the community is flourishing in view of some of the challenges experienced by its neighbors (Duffy, 2013).

Nuevo Juanillo is known by Dominicans across the country for its forced displacement by the Cap Cana luxury resort (30,000 acre resort with 12 hotels, 5.3 miles of oceanfront property). Located in the La Altagracia/ Punta Cana region, Juanillo was a fishing community until "Cap Cana representatives offered them two choices: a house in a new housing project (5 km inland) constructed for them, or a lump sum of money" (Leon, 2007: 356). While the resort followed through in building the housing, other promises (e.g. water, electricity) and gainful employment (e.g. fishing, tourism work) fell through. Most residents have since left and the resort has begun using it to house employees (Duffy, 2013; Leon, 2007).

El Macao is located directly north of Bávaro in the Punta Cana region and is largely exempt from the all-inclusive resorts. When investors began surveying the land for purchasing in $\mathrm{El}$ Macao, the residents united to prevent land purchases, due to similar occurrences in other regions. They continue to have tourists visit the area for surf lessons, ATV and dune buggy rides, and horseback riding; often these tourists are coming from resort properties (Duffy, 2013).
28 items regarding demographic and employment information, household income, and material assets. It was reviewed by the local research team prior to data collection to ensure accuracy.

Household income. This study measured household income using the methods of the Central Bank of the Dominican Republic's national survey (Banco Central $\mathrm{RD}$, 1999). The procedures included measuring monthly household cash income from work, remittances from abroad, child support, and government programs. A maximum of three activities was recorded for each member of the household and coded by industry (e.g. tourism, agriculture, fishing), and the sum of all income reported was calculated (also see
Leon, 2007). Instrument questions also distinguished between types of work: self-employed (i.e. you sell what you make, grow, catch; I have my own job), temporary worker (i.e. work odd jobs when needed; contracted on demand), wage earner (i.e. steady income from a job; hired by a business), entrepreneur (i.e. own your own business; hire people to work for you), and unpaid work (i.e. work in a family business without direct pay).

Gender and head of the household. The term "head of household" was originally created as a way to identify the chief economic provider or main decision maker of the household. However, it is also a concept imbued with gender ideology and patriarchal norms 
positioning the "man" as the person of authority (Budlender, 2003). Development projects have targeted women because their involvement is pivotal for addressing poverty and improving household standard of living; households headed by women tend to spend a larger percentage of their earnings toward household amenities and family needs such as child nutrition (Grasmuck and Espinal, 2000; Leon, 2007). Due to these differences, this study compared heads of the households by gender. Head of the household was captured in three items on the instrument: (1) Who is the main decision maker in your household (self-report), (2) who is the head of the household (self-report), and (3) who makes the largest economic contribution to the household (woman or man; calculated through reported wages)? Cronbach's alpha showed reliability across the three factors at .858 (mean $=1.352)$. As such, the self-reported head of the household variable was used as the construct for defining head of the household in this study because this is the most common technique for measurement.

Tourism dependency and households. A tourismdependent household was determined in the same way that a tourism commodity is defined; households that had over $50 \%$ of their income originating directly from tourism employment were deemed tourism dependent (Hall and Lew, 2009). Leon (2007) found that tourism-dependent households, on average, were receiving higher incomes. However, she noted that the differences between tourism and nontourism household incomes could "be explained by the fact that tourism has become not just the most attractive, but the only economic option available to locals in many communities" (354). To that end, caution should be taken in the findings as even non-tourism-dependent households in this study may still receive indirect and induced economic impacts from tourism.

Material assets. Material assets were measured by home construction material type, presence of major amenities, and presence of material lifestyle items (Table 2). Subsequently, the numbers were summed and each household was given an overall material asset score ranging from 0 (lowest level of material assets) to 17 (highest level of material assets). The initial development of this scale was based off of ideas presented in Leon (2007), though modified for this study. This is not a validated scale and caution should be taken in generalizing the results.

\section{Analysis procedures}

A multivariate analysis of covariance (MANCOVA) was performed to compare means of multiple dependent variables (Tabachnick and Fidell, 2007). Household income $\left(\mathrm{DV}_{1}\right)$ and material assets $\left(\mathrm{DV}_{2}\right)$ were examined based on the gender of the head of the household $\left(\mathrm{IV}_{1}\right)$ and whether the household was tourism dependent $\left(\mathrm{IV}_{2}\right)$, when controlling for regional differences (covariate). Region was controlled for due to the potential differences between the three regions; however, analyzing regional differences was beyond the scope of this project. All data screening tests suggested the data to be robust with the exception of a violation of the assumption of variance. However, no corrective action was taken because Box's $M$ is known for being sensitive particularly in cases where there are unequal sample sizes for each cell (Tabachnick and Fidell, 2007).

\section{Results}

A total of 376 household questionnaires were collected; however, after data cleaning, 360 surveys were included in the final analysis (Table 3). Descriptive statistics were reported and a MANCOVA conducted to examine the differences in household income and material assets between households headed by men and households headed by women as well as between tourism-dependent and non-dependent households.

\section{Demographic and descriptive data}

The respondent sample was $61.7 \%$ women, and almost two-thirds of all respondents $(62.2 \%)$ were a partner in a civil union or marriage. It should be noted that the sampling strategy of interviewing respondents at home could explain the larger portion of females in the sample. Average household size was 3.69 $(\mathrm{SD}=1.65)$ with $2.69(\mathrm{SD}=2.01)$ being children. While $11.4 \%$ of respondents had a postsecondary education, $43.3 \%$ had a secondary education, and $43.3 \%$ reported a primary education. Approximately $31 \%$ of the respondents had migrated to the current community they were living in and of those migrants, $70 \%$ had migrated in order to work specifically in the tourism industry (Table 4).

Almost $90 \%$ of the men and $41 \%$ of women reported employment outside the house. Selfemployment and wage earner were the two largest occupational areas for both women and men for a combined total of 84 and $86.6 \%$, respectively (Table 5). While almost all women respondents $(98.6 \%)$ reported completing household tasks, only $32.6 \%$ of men did the same.

The average household income per month for the sample was $\mathrm{RD} \$ 14,952.97$ (USD $\$ 334.37 ; \mathrm{SD}=$ 12,654.05) while the median household was $\mathrm{RD} \$$ 
Table 2. Material assets dimensions.

Total possible

score

\begin{tabular}{|c|c|c|c|}
\hline \multirow{3}{*}{$\begin{array}{l}\text { Home construction } \\
\text { materials }\end{array}$} & Roof & $1=$ cement $/$ concrete $0=$ zinc/wood/other & \\
\hline & Walls & $1=$ cement $/$ concrete, $0=$ wood & Max: 3 \\
\hline & Floor & $1=$ cement $/$ concrete, $0=$ wood, earthl & Min: 0 \\
\hline \multirow[t]{2}{*}{ Major amenities } & Bathroom Facilities & $1=$ Flush toilet, $0=$ Pit toilet/ None & \\
\hline & Water & $\begin{array}{l}2=\text { Piped water from aqueducts, } \\
1=\text { potable water } / \text { purchased water, } \\
0=\text { surface water }\end{array}$ & $\begin{array}{l}\text { Max: } 3 \\
\text { Min: } 0\end{array}$ \\
\hline \multirow{12}{*}{$\begin{array}{l}\text { Material lifestyle/ } \\
\text { appliances }\end{array}$} & Television & $1=$ "yes" they have the item, & \\
\hline & Radio & $0=$ "no" they don't have & \\
\hline & Refrigerator & & \\
\hline & Gas stove & & \\
\hline & Washing machine & & Max: 11 \\
\hline & Air conditioning & & Min: 0 \\
\hline & Fan & & \\
\hline & Cell phone & & \\
\hline & Bicycle & & \\
\hline & Motoconcho & & \\
\hline & Car & & \\
\hline & & Total possible score (combined): & $\begin{array}{l}\text { Max: } 17 \\
\text { Min: } 0\end{array}$ \\
\hline
\end{tabular}

Table 3. Number of surveys collected per community.

\begin{tabular}{lcl}
\hline Community & Surveys (N) & Region \\
\hline Luperón & 29 & North (38.1\%) \\
Maimón & 30 & \\
Puerto Plata & 51 & \\
Cabarete & 27 & South (39.1\%) \\
Palenque & 29 & \\
Andrés-Boca Chica & 28 & \\
Juan Dolio & 30 & \\
Boca de Chavon & 24 & East (22.8\%) \\
Bayahibe & 30 & \\
Otra Banda & 25 & \\
Nuevo Juanillo & 30 & \\
El Macao & 27 & \\
Total & 360 & \\
\hline
\end{tabular}

$11,500.00$ (USD $\$ 257.16$ ), or approximately USD $\$ 8.57$ per day (exchange rate at the time of data collection was $\mathrm{RD} \$ 39=\mathrm{USD} \$ 1)$. This study found that $44.7 \%(n=151)$ of all the households receiving income through employment $(\mathrm{n}=338)$ were tourism dependent; additionally, $66.9 \% \quad(n=241)$ of households were headed by men while $33.1 \%$ $(n=119)$ households were headed by women (Table 6$)$.
Tourism-dependent households reported that on average, $90.64 \%$ of their income $(M=R D \$$ $16,984.43, \mathrm{SD}=13,969.39$ ) was derived from tourism while those who were classified as nontourism dependent derived approximately $4.45 \%$ of their income $(M=R D \$ 891.40, \quad S D=2,739.11)$ from tourism. With regard to material assets, the overall mean score was $11.42(\mathrm{SD}=2.40$; scale of $0-17)$. The average household construction score was 2.18 $(\mathrm{SD}=.856$; scale of $0-3)$, major amenities score was $2.74(\mathrm{SD}=.452$; scale of $0-3)$, and material lifestyle score was $6.48(\mathrm{SD}=1.977$; scale of $0-11)$.

It should also be noted that there are distinct discrepancies between the three regions, where only $25.6 \%$ of the households on the North Coast, $58.8 \%$ of the households on the East Coast, and $51.2 \%$ of the households on the South Coast were considered to be tourism dependent. Likewise, average income was also different between the regions where the North Coast was $\mathrm{RD} \$ 11,270.72$ ( $\mathrm{M}=\mathrm{USD} \$ 252.03$ ), the South Coast was $\$ 16,463.58$ ( $M=U S D \$ 368.15$ ), and East Coast was $\$ 17,532.51$ ( $M=$ USD $\$ 392.05$ ).

\section{MANCOVA results}

Results of the MANCOVA indicate that the combination of the DVs, household income, and material assets was not significantly impacted by the interaction 
Table 4. Demographic information of respondents.

\begin{tabular}{|c|c|c|}
\hline $\begin{array}{l}\text { Response } \\
\text { option }\end{array}$ & Percentage & $\mathrm{N}$ \\
\hline \multicolumn{3}{|l|}{ Gender } \\
\hline Women & 61.7 & 222 \\
\hline Men & 38.3 & 138 \\
\hline \multicolumn{3}{|l|}{ Education level } \\
\hline None & 1.7 & 6 \\
\hline Primary & 43.3 & 156 \\
\hline Secondary & 43.3 & 156 \\
\hline University/higher & 11.4 & 41 \\
\hline \multicolumn{3}{|l|}{ Relationship status } \\
\hline Single & 19.7 & 71 \\
\hline Married & 18.3 & 66 \\
\hline Civil Union & 43.9 & 158 \\
\hline Separated & 13.3 & 48 \\
\hline Divorced & 1.7 & 6 \\
\hline Widowed & 3.1 & 11 \\
\hline \multicolumn{3}{|l|}{ Migrant } \\
\hline Yes $^{a}$ & 31.0 & 111 \\
\hline No & 69.0 & 247 \\
\hline \multicolumn{3}{|l|}{ Age } \\
\hline Mean & 37.4 & \\
\hline SD & 12.5 & \\
\hline \multicolumn{3}{|l|}{ Number of children } \\
\hline Mean & 2.69 & \\
\hline SD & 2.01 & \\
\hline \multicolumn{3}{|c|}{ Number of people living in household } \\
\hline Mean & 3.69 & \\
\hline SD & 1.65 & \\
\hline
\end{tabular}

${ }^{a} 70.1 \%$ of migrants $(21.7 \%$ of all respondents) moved specifically for tourism.

between gender of the head of the household and whether the household was dependent on tourism income when controlling for regional differences, as indicated by the Wilks test statistic $(\lambda=.995031$, $\mathrm{F}=.814, p=.444)$; however, there were significant main effects for the head of household's gender $(\lambda=.957698, F=7.200, p<.001)$ and household tourism dependency $(\lambda=.955629, \quad F=7.568$, $p<.001)$. Household income was significantly affected by tourism dependency $(\mathrm{F}=15.176, \mathrm{p}<.001)$ and gender of the household head $(\mathrm{F}=8.825, \mathrm{p}=.003)$. Material assets of the household were also significantly affected by the head of the household gender $(\mathrm{F}=9.526, \mathrm{p}=.002)$. The results indicated that male-headed households had a statistically higher household income than those headed by women $(\bar{X}$ difference $=4,529.39$, std. error $=1524.70, \mathrm{p}=.003$; households headed by men, $\bar{X}=16,904.78$, std. error $=793.50$; households headed by women, $\bar{X}=12,375.39$, std. error $=1,302.03$ ). Households headed by men also had a higher level of material assets than those headed by women ( $\bar{X}$ difference $=.898$, std. error $=.291, \mathrm{p}=.002$; households headed by men, $\bar{X}=11.558$, std. error $=.151$; households headed by women, $\bar{X}=10.469$, std. error $=.249$ ).

When controlling for household gender, tourismdependent households $(n=151)$ had higher levels of income $(\bar{X}$ difference $=6,077.12$, std. error $=$ $1,559.98 ; \mathrm{p}<.001$; tourism-dependent households, $\bar{X}=17,678.64$, std. error $=1,248.983$; non-tourismdependent households, $\bar{X}=11,601.52$, std. error $=$ 905.193). The effect size $\left(\eta^{2}\right)$ for tourism dependency on household income is 0.044 , for head of household gender on income is 0.029 , and head of household gender on material assets is 0.028 .

\section{Discussion of findings}

\section{Gender and head of the household}

This study confirmed previous findings that households headed by men had higher incomes (CEG, 2012) but is also contradictory as households headed by men had higher levels of overall material assets (e.g. Grasmuck and Espinal, 2000; Leon, 2007). Previous studies suggested that womenheaded households prioritize family-oriented purchases such as home appliances and amenities that improve quality of life. This discrepancy could be due to the fact that households headed by men were characteristically different from women-headed households. For example, approximately $78 \%$ of the menheaded households and only $29.4 \%$ of women-headed households were characterized by the household head being married or in a civil union (e.g. women-headed households were most often characterized as the women being separated or single). The possibility of a dual income household could account for the difference, which previous research in the DR has suggested is becoming increasingly necessary in order to meet basic household needs (Duffy et al., 2015). Additional research is needed to determine if the percentage spent directly on family needs varied between men- and women-headed households. Moreover, it is also worth noting that this study confirmed that the tourism industry is an important area of work for women as almost half of the women employed outside the home were working in the tourism industry and were largely absent from agriculture, fishing, and manufacturing. This supports previous literature that tourism is a feminized industry, offering employment 
Table 5. Occupational category and area of tourism work.

\begin{tabular}{|c|c|c|c|c|c|}
\hline & \multirow[b]{2}{*}{ Response option } & \multicolumn{2}{|l|}{ Men } & \multicolumn{2}{|c|}{ Women } \\
\hline & & $(\%)$ & $\mathrm{N}$ & $(\%)$ & $\mathrm{N}$ \\
\hline $\begin{array}{l}\text { Works outside the household } \\
\text { (e.g. employed outside the home) }\end{array}$ & (yes) & 89.9 & 124 & 41 & 91 \\
\hline $\begin{array}{l}\text { Unemployed (e.g. does not receive income } \\
\text { from employment outside the home) }\end{array}$ & & 10.1 & 14 & 59 & 131 \\
\hline \multirow[t]{5}{*}{ Occupational category ${ }^{a}$} & Self-employed ${ }^{b}$ & 33.6 & 42 & 42.6 & 39 \\
\hline & Temporary worker & 12.8 & 16 & 7.7 & 7 \\
\hline & Wage earner & 50.4 & 63 & 44.0 & 40 \\
\hline & Business owner/entrepreneur & 2.4 & 3 & 2.1 & 2 \\
\hline & Unpaid labor & 0.8 & 1 & 3.2 & 3 \\
\hline \multirow[t]{8}{*}{ Area of work ${ }^{a}$} & Tourism & 68.8 & 86 & 45.1 & 41 \\
\hline & Agriculture/farming & 0.8 & 1 & 0 & 0 \\
\hline & Fishing & 7.2 & 9 & 0 & 0 \\
\hline & Manufacturing/FTZs & 0.8 & 1 & 0 & 0 \\
\hline & Transport/trucking & 4.8 & 6 & 1.1 & 1 \\
\hline & Retail/sales/vending & 7.2 & 9 & 23.1 & 21 \\
\hline & Services (e.g. hairstylist/bank teller) & 1.6 & 2 & 24.2 & 22 \\
\hline & Other & 8.8 & 10 & 13.2 & 12 \\
\hline $\begin{array}{l}\text { Works inside the household } \\
\text { (e.g. cleaning, cooking, child care }{ }^{c}\end{array}$ & (yes) & 32.6 & 42 & 98.6 & 217 \\
\hline
\end{tabular}

${ }^{a}$ Does not include respondents who are unemployed.

${ }^{b}$ Self-employed refers to individuals who independently sell what they grow, catch, or make but does not include entrepreneurs who hire employees and have a formal business organization.

'Individuals may have been employed in work inside and outside of the home simultaneously, hence the sum of males who work outside and inside does not add up to $100 \%$.

opportunities for women outside the household (e.g. Chant, 1997).

\section{Tourism-dependent households}

Similar to Leon (2007), this study found that household income level was significantly influenced by its status as a tourism-dependent household. Households that were tourism dependent attributed as much as $90.64 \%$ of their income to tourism while nontourism-dependent households attributed only $4.45 \%$ of their income to tourism. In this regard, there appears to be a "trickledown" economic effect occurring in these communities from tourism development at the household level. However, these effects are reserved for households directly employed by the industry, such that non-tourism-dependent households likely experience the negative impacts of neoliberal tourism development without reaping the economic rewards. These results must also be contextualized by the fact that tourism appears to be the major employer (nearly $69 \%$ of males and $45.1 \%$ of females were employed by the tourism industry with the next largest industry employing only $7.2 \%$ of males-fishing, retail, and $24.2 \%$ of females-services; e.g. hairstylist, teller) and other options for household income are limited. Thus, the tourism industry in the DR may be creating jobs but at hours and wage rates that do not contribute meaningfully to total household income. This finding aligns with literature highlighting neoliberal practices that promise the creation of income stabilizing jobs, but in reality deliver low paying, seasonal, part-time substitutes (Casellas and Holocomb, 2001; Connelly et al., 2000; Gregory, 2007).

While literature enumerates the general negative influences of neoliberal economic policies dictated at a national level (e.g. Gregory, 2007), understanding the daily, on-the-ground impacts to tourismdependent households is critical for future economic strategy formation. Additionally, this study provides evidence that the DR's national dependency on tourism is felt at the household level. Thus, the concerns of overreliance and vulnerability of small island nations in the Caribbean-particularly due to the effects of climate change such as coastal erosion, sea level rise, loss of biodiversity, as well as economic and social impacts from large-scale tourism development - will need to be addressed at the household and community levels. 
Table 6. Characteristics of men-headed households and women-headed households.

\begin{tabular}{|c|c|c|c|c|}
\hline & $\begin{array}{l}\text { Men-headed } \\
\text { household }\end{array}$ & \multirow{2}{*}{$\begin{array}{l}\text { Men-headed } \\
\text { household } \\
(\%)\end{array}$} & $\begin{array}{l}\text { Women-headed } \\
\text { household }\end{array}$ & \multirow[t]{2}{*}{$\begin{array}{l}\text { Women-headed } \\
\text { household }\end{array}$} \\
\hline & Frequency & & Frequency & \\
\hline \multicolumn{5}{|c|}{ Relationship status } \\
\hline Single & 37 & 15.4 & 34 & 28.6 \\
\hline Married & 59 & 24.5 & 7 & 5.9 \\
\hline Civil union & 130 & 53.9 & 28 & 23.5 \\
\hline Separated & 13 & 5.4 & 35 & 29.4 \\
\hline Divorced & 2 & .8 & 4 & 3.4 \\
\hline Widowed & 0 & 0 & 11 & 9.2 \\
\hline \multicolumn{5}{|c|}{ Number of children } \\
\hline Mean & \multicolumn{2}{|c|}{2.63} & \multicolumn{2}{|c|}{2.81} \\
\hline SD & \multicolumn{2}{|c|}{2.05} & \multicolumn{2}{|c|}{1.90} \\
\hline \multicolumn{5}{|c|}{$\begin{array}{l}\text { Number of people living } \\
\text { in household }\end{array}$} \\
\hline Mean & \multicolumn{2}{|c|}{3.74} & \multicolumn{2}{|c|}{3.58} \\
\hline SD & \multicolumn{2}{|c|}{1.55} & \multicolumn{2}{|c|}{1.84} \\
\hline \multicolumn{5}{|c|}{ Household income } \\
\hline Mean & \multicolumn{2}{|c|}{ RD\$ 16,151.49 } & \multicolumn{2}{|c|}{ RD\$ 9496.13} \\
\hline SD & \multicolumn{2}{|c|}{ RD\$ 13,519.13 } & \multicolumn{2}{|c|}{ RD\$ 9711.68} \\
\hline \multicolumn{5}{|c|}{ Number of tourism-dependent households } \\
\hline & 122 & 50.6 & 37 & 26.9 \\
\hline
\end{tabular}

For tourism to be most economically beneficial to a destination, local business ownership and entrepreneurship is imperative (Scheyvens and Momsen, 2008). However, the lack of small businesses and entrepreneurial opportunities in DR destinations dominated by enclave tourism reiterates the findings by Roessingh and Duljnhoven (2005), who investigated tourism development in Puerto Plata and found that the local entrepreneurs had limited success due to neoliberal economic policy that favored large-scale transnational development. This study suggests that there is limited economic "trickledown" occurring from the large-scale enclave tourism projects.

\section{Limitations}

These findings indicate that foreign-owned MNCs and TNCs provide an economic benefit to select regions of the DR; however, the sample size and sampling method limit generalizability. Future research should account for population differences in each of the communities with regard to sampling size. Moreover, regional differences were detected during field work and controlled for in the analysis; future studies should explore the nuanced differences of the political economy in each of the three regions to better understand the scope of the country as a whole.
This study employed an indirect measure of economic impact using the household as the unit of analysis; however, this approach has been criticized for its simplistic nature, as it fails to assess the induced and indirect effects. Detailed questions regarding employment and resource acquisition were asked of all household members; however, this issue may not have been fully addressed. A clear evaluation of the economic benefit and leakage experienced by and through TNCs and MNCs was also excluded from this study as it would be difficult to compare benefits experienced at the household and corporate levels, partially due to the lack of corporate data.

\section{Implications and future research}

The concern resonating from this study is whether the neoliberal economic policies that have shaped the tourism industry in the DR have provided sufficient economic benefits to households in the coastal communities. This study suggests that those who work in the tourism industry are better off financially. Another telling finding from the present study indicated that the majority of respondents are wage earners or selfemployed, rather than entrepreneurs and business owners suggesting that the economic policy has stifled the local economic ecosystem. What is difficult to assess through the methods employed in this study is 
the "what if" factor; if fewer TNCs dominated the landscape, would we find more local entrepreneurs and small business owners in their place?; would wages be higher as a result of decreased economic leakage and repatriation?; or, if fewer TNCs dominated the landscape, would the structure of the labor force allow for more upward movement of local Dominicans, and thus higher household incomes and access to material assets? Further research is also needed to tease out additional quality-of-life questions raised here. For example, are there social and environmental costs that outweigh the economic gain? Are the opportunities for economic gain available to all community members or select local elite? How has the high level of migration of tourism employment changed or weakened the family/household structures? For example, are some rural origin locations becoming depopulated and do the receiving areas have the necessary infrastructure for a $21.7 \%$ increase in population?

The distribution of tourism benefits, particularly economic, should be examined to determine if the allocation of financial benefits is equitable among stakeholders. Significant relationships between the independent variables (head of household, tourism dependency) and the dependent variable (household income) were detected in this study. Thus, future research should also explore how and why these relationships vary by region. Tourism planners and developers must appreciate the structures that create differential impacts in order to help mitigate the widening gap between rich and poor (Gregory, 2007). Pro-poor tourism development policies may be warranted to improve the standard of living for the local residents (Hall, 2003; Harrison, 2008). Specifically, the linkages and value chains between tourism and traditional economic sectors need to be identified and examined to create additional, higher paying forms of employment and strengthen existing local businesses (Van de Mosselaer and Van der Duim, 2012).

Likewise, focused action could help restore the informal tourism sector, which is often where large portions of residents, particularly those who are less skilled and less educated, are employed, subsequently providing them direct access to tourism income. However, typical enclave models do not promote the informal tourism sector, as resident interactions with tourists are structurally discouraged and limited (Carlisle, 2010; Freitag, 1994). Similarly, attention should be paid to providing resources, education, and training to local residents to develop more successful entrepreneurs and small business owners. However, for this to be effective there would need to be collaboration with the large-scale tourism projects to negotiate more opportunities for interaction between tourists and local small businesses. Moreover, there could be human resource and hiring policies that focus on the employment and promotion of local residents in order to strengthen the connection to the local communities.

Whether or not tourism is economically advantageous to the poorer local households remains a question for future research; of particular concern is the maturity of the tourism product observed during data collection in many of the communities suggests a decline in tourism could be possible if policies do not address environmental and cultural degradation. This issue is interrelated with employment concerns, because after tourism becomes established, policy that prevents the overdevelopment and overuse of resources, including increased pressure on traditional industry sectors (e.g. fishing and agriculture) can be more difficult to authorize. The role of women in tourism needs more exploration, as tourism employment is outside of the home, which may help increase women's status (Duffy et al., 2015; Leon, 2007). Additional research is also needed to determine how tourism is affecting women and challenging traditional machismo-marianismo ideologies.

\section{Conclusion}

This study examined whether tourism development resulted in economic impacts at a household level, namely in the form of household income and material assets in Dominican coastal communities. The analysis focused on differences in these variables across gender of the head of the household and dependency on tourism, while adjusting for regional differences, and reiterates questions that others have raised as to how tourism benefits residents in LEDCs (Leon, 2007; Mitchell and Ashley, 2010; Scheyvens and Momsen, 2008). Due to a neoliberal economic agenda, the DR currently faces high levels of income inequality (Hammill, 2005), and foreign-owned, large-scale, enclave tourism projects may only exacerbate the inequality (Buncic, 2008; Carlisle, 2010; Freitag, $1994,1996)$. To the question of whether the rural households are receiving a "trickledown effect" from tourism, the short answer is yes; however, many questions remain as to whether they are benefiting as much as they could. Understanding "who benefits" from tourism requires an understanding of the power structures that control tourism (Ateljevic et al., 2012; Bianchi, 2009). Likewise, understanding the farreaching impacts of neoliberal economic policy is difficult at best. Acknowledging neoliberalism as it relates to the growing international tourism industry in LEDCs and small island nations such as the DR is 
paramount for tourism researchers exploring the impacts of tourism development in LEDCs.

\section{References}

Abdullaev U and Estevao M (2013) Growth and employment in the Dominican Republic: Options for a job-rich growth. Available at: http://www.imf.org/external/pubs/ft/wp/2013/wp1340.pdf (accessed 17 March 2013).

Association of Hotels and Tourism in the Dominican Republic [ASONAHORES] and the Central Bank of the Dominican Republic (2013) Indicators of hotels, bars, and restaurants 1980-2012. Available at: http://www.bancentral.gov.do/english/ statistics.asp?a=Tourism_Sector (retrieved 23 February 2013).

Ateljevic I, Morgan N and Pritchard A (2012) The Critical Turn in Tourism Studies: Creating an Academy of Hope. London: Routledge.

Banco Central RD. Encuesta Nacional de Ingresos y Gastos de los hogares. Tomo I. Metodología. Santo Domingo, RD: Departmente De Cuentas Nacionales y Estadisticas Economicas.

Baran PA (1957) The Political Economy of Growth. New York: Monthly Review Press.

Barrera B, Gjurcilova P, Rabinowitz S, et al. (2008) Tourism in the Dominican Republic. Available at: http://www.isc.hbs.edu/pdf/ Student_Projects/DominicanRepublic_TourismCluster_2007. pdf (retrieved 28 March 2013).

Bianchi RV (2009) The 'critical turn' in tourism studies: A radical critique. Tourism Geographies 11: 484-504.

Bramwell B (2011) Governance, the state and sustainable tourism: A political economy approach. Fournal of Sustainable Tourism 19: 459-477.

Brennan D (2004) When sex tourists and sex workers meet: Encounters within Sosua, the Dominican Republic. In: Gmelch SB (ed.) Tourists and Tourism: A Reader. Long Grove, IL: Waveland Press, Inc, pp. 303-317.

Budlender D (2003) The debate about household headship. Social Dynamics 29: 48-72.

Bulmer-Thomas V (2012) The Economic History of the Caribbean Since the Napoleonic Wars. New York, NY: Cambridge University Press.

Buncic AD (2008) The Critical Relationship Between Large Resorts and the State in Developing Sustainable Tourism in the Caribbean: The Case of the Dominican Republic. Burnaby, British Columbia: Dept. of Political Science-Simon Fraser University.

Cabezas AL (2004) Between love and money: Sex, tourism, and citizenship in Cuba and the Dominican Republic. Signs 29: 987-1015.

Carlisle S (2010) Access and marginalization in a Beach Enclave Resort. In: Cole $\mathrm{S}$ and Morgan $\mathrm{N}$ (eds) Tourism and Inequality: Problems and Prospects. Cambridge, MA: CABI International, pp. 67-84.

Casellas A and Holocomb B (2001) Gender, tourism, and development in Latin America. In: Apostolopoulos Y, Sönmez S and Timothy D (eds) Women as Producers and Consumers of Tourism in Developing Regions. Westport, CT: Praeger Publishers, pp. $143-166$.

Centro de Estudios de Género (CEG) (2012) Situación de las Mujeres en la República Dominicana, 2011. Retrieved on March 28, 2013. Available at: http://www.magda-rodriguez.org/ Situacion\%20de\%20las\%20Mujeres\%202011_7marzo_2012. pdf (retrieved 28 March 2013).

Chant S (1997) Gender and tourism employment in Mexico and the Philippines. In: Sinclair MT (ed.) Gender, Work and Tourism. London: Routledge, pp. 119-178.

Classical Reality International (n.d.) Cap Cana. Available at: http:// www.classicalrealtyint.com/Web/AR410690/CustomContent/ index/5061837 (retrieved 17 March 2013.
Connelly MP, Li TM, MacDonald M, et al. (2000) Feminism and development: Theoretical perspectives. In: Parpart JL, Connelly $\mathrm{P}$ and Barriteau E (eds) Theoretical Perspectives on Gender and Development. Ottawa, ON: International Development Research Center, pp. 51-159.

David M (2002) Problems of participation: The limits of action research. International fournal of Social Research Methodology 5: 11-17.

Dominican Today (2011) Carnival announces US $\$ 65 \mathrm{M}$ cruise port in Dominican Republic. Available at: http://www.dominicantoday.com/dr/tourism/2011/8/12/40578/Carnival-announcesUS65M-cruise-port-in-Dominican-Republic (retrieved 3 April 2014).

Duffy LN (2013) An examination of tourism development in coastal communities in the Dominican Republic: Moving towards sustainable tourism development as a mechanism for social justice. Unpublished doctoral dissertation. Indiana University, Bloomington, IN.

Duffy LN, Kline CS, Mowatt RA, et al. (2015) Women in tourism: Shifting gender ideology in the DR. Annals of Tourism Research 52: 72-86.

Duffy LN, Mowatt RA, Chancellor HC, et al. (2012) Machismomarianismo and the involvement of women in a communitybased tourism project in Ecuador, South America. Tourism Analysis 17: 791-803.

Ferguson J (2001a) Dominican Republic Economy. South America, Central America and the Caribbean 2002 10: 337-341.

Ferguson J (2001b) Dominican Republic History. South America, Central America and the Caribbean 2002 10: 335-337.

Ferguson L (2010a) Tourism as a development strategy in Central America: Exploring the impact on women's lives. Central America Women's Network. Briefing Paper. Available at: http://centralamerica.myzen.co.uk/assets/Tourism $\% 20 \mathrm{as} \% 20 \mathrm{a} \%$ 20development $\% 20$ strategyFINAL.pdf (retrieved 14 October 2015).

Ferguson L (2010b) Tourism development and the restructuring of social reproduction in Central America. Review of International Political Economy 17: 860-888.

Folbre N (1986) Hearts and spades: Paradigms of household economics. World Development 14: 245-255.

Frank AG (1967) Capitalism and underdevelopment in Latin America. New York: Monthly Review Press.

Freitag TG (1994) Enclave tourism development: For whom the benefits roll? Annals of Tourism Research 21: 538-554.

Freitag TG (1996) Tourism and the transformation of a Dominican coastal community. Urban Anthropology and Studies of Cultural Systems and World Economic Development 25(3): 225-258.

Grasmuck S and Espinal R (2000) Market success or female autonomy? Gender and Society 14: 231-255.

Gregory S (2007) The Devil Behind the Mirror: Globalization and Politics in the Dominican Republic. Berkeley and Los Angeles, CA: University of California Press.

Hall CM (1994) Tourism and Politics: Policy, Power and Place. New York, NY: John Wiley \& Sons.

Hall CM (2003) Politics and place: An analysis of power in tourism communities. In: Singh S, Timothy DJ and Dowling RK (eds) Tourism in Destination Communities. Cambridge, MA: CABI Publishing, pp. 99-114.

Hall CM and Lew AA (2009) Understanding and Managing Tourism Impacts: An Integrated Approach. New York: Taylor \& Francis.

Hammill M (2005) Income Inequality in Central America, Dominican Republic and Mexico: Assessing the Importance of Individual and Household Characteristics. United Nations Publications.

Harrison D (2008) Pro-poor tourism: A critique. Mexico: Third World Quarterly 29: 851-868. 
Higgins-Desbiolles F (2008) Justice tourism and alternative globalisation. Fournal of Sustainable Tourism 16: 345-364.

Hotel News Resource (2015) AMResorts announces five new resort contracts during Q1 2015. Available at: http://www.hotelnewsre source.com/article82796.html (accessed 15 May 2015).

International Center for Prison Studies (2014) Dominican Republic. Available at: http://www.prisonstudies.org/country/ dominican-republic (accessed 1 September 2015).

Kermath BM and Thomas RN (1992) Spatial dynamics of resorts: Sosua, Dominican Republic. Annals of Tourism Research 19: 173-190.

Kincheloe J and McLaren P (2008) Rethinking critical theory and qualitative research. In: Denzin NK and Lincoln YS (eds) The Handbook of Qualitative Research, 2nd ed. Thousand Oaks, CA: Sage.

Leon YM (2007) The impact of tourism on rural livelihoods in the Dominican Republic's coastal areas. Fournal of Development Studies 43: 340-359.

Mikkelsen B (2005) Methods for Development Work and Research: A New Guide for Practitioners. Thousand Oaks, CA: Sage Publications.

Mitchell J and Ashley C (2010) Tourism and Poverty Reduction: Pathways to Prosperity. Washington, DC: Earthscan/James \& James.

Momsen J (2004) Gender and Development. New York: Routledge.

Mosedale J (2011) Political Economy of Tourism: A Critical Perspective. New York, NY: Taylor \& Francis.

Peet R (1991) Global Capitalism: Theories of Societal Development. London: Routledge.

Pozo S, Sánchez-Fung JR and Santos-Paulino AU (2010) Economic Development Strategies in the Dominican Republic. Helsinki, Finland: World Institute for Development Economics Research.

Raynolds LT (2002) Wages for wives: Renegotiating gender and production relations in contract farming in the Dominican Republic. World Development 30: 783-798.

Roessingh C and Duijnhoven H (2005) Small entrepreneurs and shifting identities: The case of tourism in puerto plata (northern Dominican Republic). Fournal of Tourism and Cultural Change 2(3): 185-202.

Roessingh C, Duljnhoven H and Berendse M (2008) Small entrepreneurs and shifting identities: the case of tourism in puerto plata (northern dominican republic). Fournal of Tourism and Cultural Change 2: 185-202.

Sasidharan V and Hall ME (2012) Dominican resort tourism, sustainability, and millennium development goals. Fournal of Tourism Insights 3: 5 .

Scheyvens R and Momsen JH (2008) Tourism and poverty reduction: Issues for small island states. Tourism Geographies 10: $22-41$.

Tabachnick BG and Fidell LS (2007) Using Multivariate Statistics, 5th ed. Boston: Pearson Education.

U.S. Department of State (2014) Dominican Republic 2014 Crime and Safety Report. Available at: https://www.osac.gov/pages/ ContentReportDetails.aspx?cid=16417 (accessed 1 September 2015).

Van de Mosselaer F and Van der Duim R (2012) Tourism and the explicit concern with poverty reduction: A review. In: Bricker K, Black R and Cottrell S (eds) Sustainable Tourism and The Millennium Development Goals: Effecting Positive Change. Burlington, MA: Jones \& Bartlett Learning, pp. 39-56.
Wellisz S (1968) Dual economies, disguised unemployment and the unlimited supply of labour. Economica 35(137): 22-51.

Wiarda HJ (2005) Dilemmas of Democracy in Latin America: Crises and Opportunity. Oxford: Rowman \& Littlefield.

Wilkinson PF (1989) Strategies for tourism in island microstates. Annals of Tourism Research 16: 153-177.

Wilkinson PF (2009) Predictions, past and present: World and Caribbean tourism. Futures 41: 377-386.

Williams AM (2004) Toward a political economy of tourism. In: Lew AA, Hall CM, and Williams AM (eds) A companion to tourism, Malden, MA: Blackwell Publishing, pp. 61-73.

World bank data (2013) Data: Dominican Republic. Available at: http://data.worldbank.org/country/dominican-republic (retrieved 14 July 2014).

World Travel \& Tourism Council (WTTC). Travel \& Tourism Economic Impact 2012: Dominican Republic. London: WTTC.

\section{Author Biographies}

Lauren Duffy is an Assistant Professor in the Department of Parks, Recreation, and Tourism Management at Clemson University. Her research interests include power and ideology in tourism planning, social and environmental justice, and critical thinking in the classroom.

Garrett Stone, M.S. is a $\mathrm{PhD}$ student in the Department of Parks, Recreation, and Tourism Management at Clemson University. His background includes planning, implementing, and evaluating therapeutic and didactic, domestic and international programs for youth and young adults. Currently, his research is focused on critical pedagogy and cross-cultural adaptation.

H Charles Chancellor is an Associate Professor in the Department of Parks, Recreation, and Tourism Management at Clemson University. His research interests include land trusts collaboration with tourism entities, sustainable tourism, bicycle tourism and bicycling as a community development tool.

Carol S Kline is an Associate Professor of Hospitality and Tourism Management at Appalachian State University in the Department of Management. Her research interests focus broadly on tourism planning and development and tourism sustainability but cover a range of topics such as foodie segmention, craft beverages, agritourism, animal welfare in tourism, tourism entrepreneurship, niche tourism markets, and tourism impacts to communities. 